\title{
ABSURDITAS DALAM DRAMA DAG DIG DUG KARYA PUTU WIJAYA DAN NOVEL PAYUDARA KARYA CHAVCHAY SYAIFULLAH (SASTRA PERBANDINGAN)
}

\author{
Slamet Riyadi; Ridlwan; Ali Nuke Affandy \\ SD Negeri Branta Paseser 3; Universitas Muhammadiyah Surabaya \\ slamet.riyadi.wrb@gmail.com
}

ABSTRAK

ABSTRACT
Penelitian ini bertujuan memberikan deskripsi secara kualitatif tentang absurditas prilaku yang terdapat dalam drama Dag Dig Dug karya Putu Wijaya dan novel Payudara karya Chavchay Syaifullah. Penelitian ini menggunakan rancangan penelitian dengan metode deskriptif, sedangkan pendekatan yang digunakan adalah kualitatif. Teknik pengumpulan data berupa observasi dan dokumentasi. Hasil penelitian ini adalah (1) absurditas perilaku dalam drama Dag Dig Dug karya Putu Wijaya dimunculkan oleh tokoh suami, istri, tamu, Cokro, dan Ibrahim yang aneh; (2) absurditas perilaku dalam novel payudara karya Chavchay Syaifullah ditunjukkan oleh perilaku tokoh Bayu yang tidak masuk akal, tokoh Sakti yang berperilaku gila, tokoh Komandan yang ingin membunuh tanpa sebab, dan Tokoh Martin yang ingin menyambut kemeriahan perkawinan tokoh Bayu dan Isabela (setan wanita); (3) persamaan absurditas perilaku dalam drama Dag Dig Dug karya Putu Wijaya dan novel Payudara karya Chavchay Syaifullah ditandai oleh hal-hal yang bersifat irrasional atau di luar nalar dan tidak masuk akal; (4) Perbedaan absurditas perilaku dalam drama Dag Dig Dug karya Putu Wijaya dan novel Payudara karya Chavchay Syaifullah terletak pada penggunaan setting dan konflik, drama dag dig dug settingnya moton hanya di sekitar lingkungan rumah dan pekuburan dan konfliknya hanya membahas tentang kematian tokoh chairul umam, sedangkan dalam novel payudara settingnya lebih banyak, dan konflik yang dimunculkan lebih beragam seperti perkawinan dengan setan, berbicara dengan lukisan, dan bergerak seperti mayat.

Kata Kunci: Absurditas, Drama, Novel, Sastra Perbandingan.

This study uses a study design with descriptive method, whereas the approach used is qualitative. Data collection techniques such as observation and documentation. The results of the study as follows: First, the absurdity of the behavior in the drama "Dag Dig Dug" of Putu Wijaya's works raised by husband figure, wives, guests, Cokro, and the strange man named Ibrahim. Secondly, the absurdity of the behavior in novel "Payudara" of Syaifullah Chavchay's works shown by unreasonable behavior of leaders that is Bayu, figure of Sakti who behave insanely, figure of commander who wanted to kill without cause, and figure of Martin who wanted to welcome the festive marriage of figure of Bayu and Isabela 
(devil woman). Third, equation the absurdity of the behavior in the drama "Dag Dig Dug" of Putu Wijaya's works and and novel "Payudara" of Syaifullah Chavchay's works is characterized by unreasonable things or beyond reason and sometimes make no sense. Fourth, differences the absurdity of the behavior in the drama "Dag Dig Dug" of Putu Wijaya's works and and novel "Payudara" of Syaifullah Chavchay's works lies in the using of setting and conflict, the pelce of setting in drama "dag dig dug" is monotonous, it is just around the home environment and the cemetery, and the conflict is only discussed about the death of chairul umam, while the setting in novel " Payudara" has more places, and the conflicts that appear is diverse such as a marriage with the devil, talking with paintings, and moves like a corpse.

\section{Keywords: Absurdity, Drama, Novel, Comparative Literature}

PENDAHULUAN

Ia mengenalkan pengalaman-pengalaman yang berhubungan langsung dengan sisi-sisi kehidupan. Pengalaman kemanusiaan yang ada dalam karya sastra bukan semata-mata sesuatu yang kasat mata atau dapat teramati dalam kehidupan sehari-hari, namun kadang-kadang berisi hal-hal yang liar, aneh, asing, dan gaib, yang mungkin tidak bisa dinalarkan oleh akal. Pengalaman yang demikian biasanya menyimpan maksud tertentu serta berisi sesuatu yang bersifat samar.

Karya sastra yang bersifat samar memiliki keunikan sebagai ciri kekhasannya. Keunikan ini wajar-wajar saja karena setiap pengarang bebas mengekspresikan jati diri, sehingga tidak lagi terbelenggu oleh keteraturan yang dianggapnya sebagai pengahambat munculnya kreasi. Kebebasan berekspresi tersebut lambat laun mulai mendapat perhatian dari kalangan pengarang dan pembaca seiring dengan perkembangan sastra postmodern.

Situasi sastra postmodern atau sesudah modern cenderung mempertentangkan atau menampilkan gejala lain secara samar sebagai wujud perubahan besar peradapan manusia. Perubahan tersebut selanjutnya berpengaruh pada perubahan konsep yang menyebutkan bahwa tak ada sesuatu yang tidak mungkin. Konsep tersebut didasarkan pada asumsi bahwa tidak ada lagi batas-batas alam fisik dunia, tak ada lagi kebenaran yang sejati dan tetap abadi. Konsep yang demikian merupakan awal lahirnya paham atau aliran absurditas, yakni paham yang menganggap kehidupan penuh dengan kekonyolan nasib manusia sebagai bagian dari pemberontakan yang disembunyikan (Copperfield dalam Faruk, 2001:154).

Masalah absurditas dengan berbagai konsepnya banyak diangkat pengarang melalui tokoh-tokohnya dalam karya sastra, khususnya dalam karya sastra berjenis prosa dan drama. Karya sastra bernuansa absurd dapat dijumpai dalam karya-karya Putu Wijaya bergenre drama yaitu Dag Dig Dug. Sedangkan karya sastra bermuatan absurditas jenis prosa lebih banyak dijumpai pada 
bentuk novel. Salah satu novel yang dapat digolongkan ke dalam novel absurd adalah Payudara karya Chavchay Syaifullah.

Penelitian tentang absurditas khususnya dalam drama Dag Dig Dug karya Putu Wijaya pernah dilakukan oleh saudara I Nyoman Yasa dengan judul Absurditas dalam Drama Dag Dig Dug karya Putu Wijaya. Hasil penelitiannya menunjukkan bahwa absurditas dalam drama Dag Dig Dug ditandai oleh adanya tokoh yang namanya tidak jelas, alur yang memutar, dan dialog yang tidak memiliki hubungan antara satu dengan yang lain.

Nuansa absurditas yang akan diteliti oleh peneliti dalam drama Dag Dig Dug lebih memfokuskan pada irrasionalitas yang ada atau fenomena realitas yang melampaui batas realitas biasa. Perbedaan kajian ini membuat peneliti tertarik untuk menelitinya lebih lanjut dengan membandingkan nuansa absurditas lintas genre sastra, yakni drama dan prosa.

Penelitian lain yang memiliki relevansi dengan absurditas juga dilakukan oleh saudara Emzir dalam bentuk buku berjudul Estetika Ketiadaan dalam Novel Perempuan Berkalung Surban: sebuah Kajian Postmodernisme. Hasil penelitian menggambarkan bahwa estetika ketiadaan yang bertolak dari paham postmodernisme memandang bahwa keindahan novel Perempuan Berkalung Surban tidak terikat pada keindahan bentuk dan isi, seperti yang terjadi pada karya sastra modern. Keindahan ketiadaan dapat dilacak melalui penggunaan bahasa yang tidak jelas dan inkonsisten sebagai bagian dari ciri-ciri absurditas.

Titik tekan penelitian I Nyoman Yasa adalah absurditas dilihat dari nama tokoh, alur, dan dialog, sedangkan titik tekan penelitian Emzir adalah absurditas dilihat dari estetika ketiadaan. Sedangkan Penulis lebih memfokuskan pada absurditas perilaku dalam kedua genre sastra tersebut.

Perbedaan objek sekaligus perbedaan kajian inilah yang menjadi alasan lain peneliti untuk mengangkatnya ke dalam sebuah penelitian tesis bernuansa absurditas dalam drama Dag Dig Dug karya Putu Wijaya dan novel Payudara karya Chavchay Syaifullah. Hanya saja, kajian terhadap drama cenderung tidak sekompleks kajian pada novel.

Tujuan umum penelitian ini untuk mendeskripsikan Absurditas dalam drama Dag Dig Dug karya Putu Wijaya dan novel Payudara karya Chavchay Syaifullah. Tujuan khusus penelitian ini adalah memberikan deskripsi secara objektif tentang absurditas dalam drama Dag Dig Dug karya Putu Wijaya dan novel Payudara karya Chavchay Syaifullah yang berorientasi pada mendeskribsikan absurditas perilaku dalam drama Dag Dig Dug karya Putu Wijaya, mendeskrisikan absurditas perilaku dalam novel Payudara karya Chavchay Syaifullah, mendeskripsikan persamaan absurditas perilaku dalam drama Dag Dig Dug karya Putu Wijaya dan novel Payudara karya Chavchay Syaifullah, dan mendeskripsikan perbedaan absurditas perilaku dalam drama Dag Dig Dug karya Putu Wijaya dan novel Payudara karya Chavchay Syaifullah. 
METODE

\section{PEMBAHASAN Deskripsi Data Kualitatif Absurditas Perilaku dalam Drama Dag Dig Dug karya Putu Wijaya}

Perilaku dalam konteks absurditas menyaran pada tindakan atau praktik tokoh yang aneh, yakni tindakan yang tidak dapat dinalar secara logika umum, irrasional, dan tidak dihubungkan dengan sifat-sifat umum manusia dalam dunia nyata serta penuh kontradiksi perilaku.

Kontradiksi perilaku tokoh pada drama absurd menimbulkan perilaku yang aneh. Perilaku aneh tersebut dapat digambarkan sebagai berikut: (1) terjadinya pengulangan perilaku tanpa makna; (2) tokoh berada dalam kondisi alinasi, yakni keadaan tertindih oleh kondisi yang tidak jelas; (3) perilaku tokoh terkadang menyedihkan sekaligus lucu, layaknya perilaku badut dalam pertunjukan di pertunjukan sirkus; (4) perlakuan tokoh yang kurang dihargai sebagai manusia; (5) perilaku tokoh dalam peperangan yang dianggap sesuatu yang konyol dan jahat; dan (6) perilaku tokoh 
yang tidak bermoral dianggap yang baik atau perilaku tokoh seolaholah memperjuangkan moralitas padahal timpang dan penuh kepalsuan (Saini dalam Dewojati, 2010:69-79).

Absurditas bentuk perilaku dalam drama Dag Dig Dug karya Putu Wijaya dapat dilihat pada beberapa kutipan data berikut.

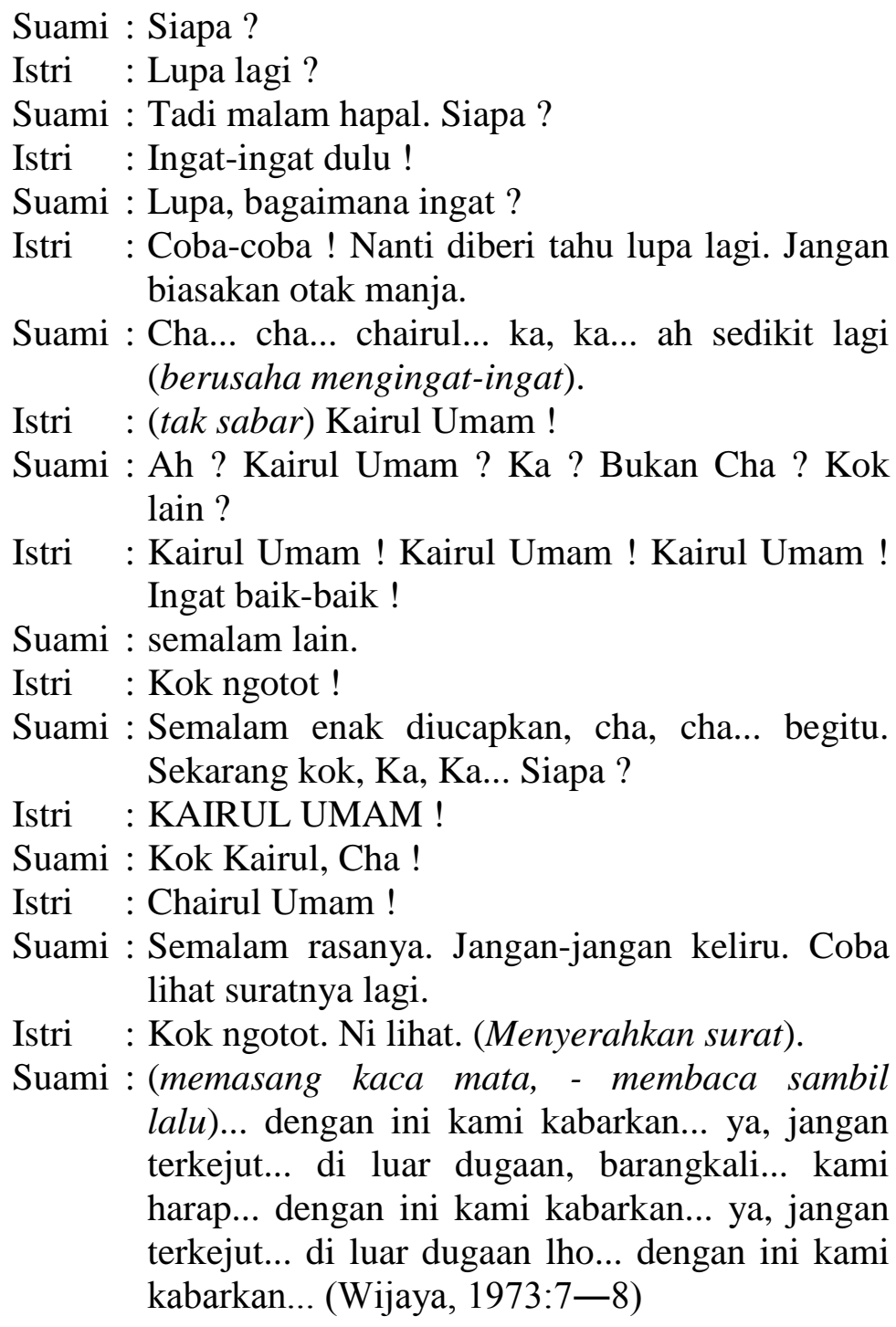

Istri : Kok ngotot. Ni lihat. (Menyerahkan surat).

Suami : (memasang kaca mata, - membaca sambil lalu)... dengan ini kami kabarkan... ya, jangan terkejut... di luar dugaan, barangkali... kami harap... dengan ini kami kabarkan... ya, jangan terkejut... di luar dugaan lho... dengan ini kami kabarkan... (Wijaya, 1973:7-8)

Data di atas mengisyaratkan adanya perilaku tokoh suami yang berperilaku konyol, yakni lupa akan sesuatu yang sudah diketahui tentang tokoh Chairul Umam, sehingga tokoh suami seakan-akan berlaku tanpa nalar yang ditunjukkan dengan keterkejutan.

Absurditas bentuk perilaku juga di tandai oleh sikap tokoh suami yang memperlihatkan kebingungan tentang adanya tokoh Chairul yang tidak dikenalnya tiba-tiba hadir dalam benaknya, sehingga menimbulkan perilaku bertindak sendiri berupa persepsi bahwa dirinya adalah keluarganya.

Suami : Aku tidak ingat Tobingmu. Dan Chairul, Chairul... tampangnya kumis? Putih? Hatinya baik? Tidak ingat. Sedih juga rasanya orang 
Absurditas dalam Drama Dag Dig Dug Karya Putu Wijaya dan Novel Payudara Karya Chavchay Syaifullah (Sastra Perbandingan)

yang pernah kenal mati di sana. Sedih lagi aku tak ingat apa-apa.

(keduanya diam)

Suami : Dikubur keesokan harinya di Menteng Pulo. Di mana Menteng Pulo? Aku tahu kuburan di Jakarta yang bernama Karet. (pause) Ditabrak motor dari belakang. Kepala patah. Ditolong oleh kere-kere. Yang menabrak lari. Mulai lumrah sekarang. Motor terlalu murah, padahal berbahaya. Perlu selamatan?

Istri : Ah?

Suami : Selamatan.

Istri : Mmmm.

Suami : Kita dianggap keluarga kan ?

Istri : Hhh?

Suami : Dalam surat (mengingat)... setelah membongkar kami berhasil menemukan alamat bapak sekeluarga, yang kami kira adalah keluarganya yang paling dekat. Jadi dia nyimpan alamat kita.

Istri : Tentu. Apa aku pernah kirim surat kepadanya ?

Suami : Surat itu mereka baca.

Istri : Ya.

Suami : Tentu aku menyebut ananda. Memanggil diriku ayahanda. Begitu biasanya. Salahnya kalau tidak punya anak, semua orang seperti anak sendiri. Dan mereka mengira kita keluarganya. Tak apa. Salahnya aku tidak ingat siapa ChairulChairul ini. Chairul siapa ? Namanya bagus. Chairul Umam. Sekarang hapal. Agak pendek ya? (Wijaya, 1973:10—11)

Perilaku aneh tokoh suami ditandai pula oleh adanya perilaku aneh tokoh suami dan bertindak sendiri yang mempersiapkan penguburan tokoh Chairul, padahal tokoh tersebut tidak ada hubungan keluarga dengannya.

Tamu I : Kami gembira, dapat datang ke mari mengabarkan.

Suami : O, kami juga gembira penguburannya sudah dengan sebaik-baiknya.

Tamu II : Hari itu Minggu, Chairul adalah orang yang sangat kami butuhkan.

Suami : Ya, ya!

Tamu I : Kami baru beberapa bulan bekerja sama, tapi rasanya sudah lama sekali, karena ada kecocokan.

Suami : Ya, ya.

Tamu II : Tidak ada orang yang benci kepadanya, karena ia polos. 
Suami : Memang.

Tamu II : Ia selalu menutupi kehidupan pribadinya, bahkan sampai pondokannya tidak kami ketahui, setelah semalam suntuk mencari baru ketemu.

Tamu I : Anehnya lagi, beberapa hari setelah dia meninggal, seorang perempuan yang tinggal di rumah sebelahnya mati menggantung diri.

Tamu II : Saya kira baiknya dijelaskan Bapak ini bagaimana keadaannya pada saat-saat terakhir, soal perempuan itu.

Tamu I : Ya, tapi kau ingat, maaf...

Suami : Silahkan! (Wijaya, 1973:14-15).

Gambaran adanya perilaku tokoh suami yang bertindak sendiri seakan-akan sudah mengenal tokoh Chairul dengan berbagai keistimewaannya, padahal ia belum tahu tokoh Chairul sebelumnya.

\section{Deskripsi Data Kualitatif Absurditas Perilaku dalam Novel Payudara karya Chavchay Syaifullah}

Kutipan di bawah ini menggambarkan adanya absurditas perilaku, yakni tokoh aku yang berperilaku tidak rasional atau tidak bisa dicerna dengan akal sehat karena ia berkeinginan untuk menulis surat cinta kepada tokoh Payudara, sedangkan ia tidak tahu rupa dan fisik tokoh tersebut karena keadaannya atau sosoknya belum jelas. Tokoh tersebut juga belum diketahui apakah ia seorang manusia, setan, bayangan, khayalana, ataukah sekadar lukisan, yang jelas ia ingin menulis surat tanpa tahu alamatnya dan yang dituju tanpa bentuk atau tidak jelas identitasnya.

"Baik, akan kubuktikan kalau aku mampu menulis surat cinta untuk Payudara. Tapi bagaimana mungkin surat itu bisa sampai ke tangannya? Aku tak tahu alamat Payudara. Jangankan alamatnya, wujud sebenarnya saja, aku tak tahu. Sampai kini aku belum tahu pasti apakah Payudara itu manusia, setan, bayangan, khayalan, ataukah sekadar lukisan? Aku belum tahu," Sakti membatin kuat-kuat. (Syaifullah, 2004:19)

Tokoh aku (Bayu) juga melakukan absurditas perilaku karena dirinya bukan hanya sekadar ingin menulis surat kepada tokoh Payudara, namun tokoh Bayu lebih jauh berkeinginan untuk mencintai tokoh Payudara, padahal ia tahu bahwa Payudara adalah sosok yang tanpa bentuk atau tidak diketahui kondisi fisiknya serta tidak jelas identitas dan asal usulnya dalam kehidupan di dunia, sehingga ia dihadapkan pada kebingungan-kebingungan yang tidak menentu bahkan dirinya tidak tahu apa yang harus ia perbuat dan bagaimana cara melakukannya. Kutipan berikut menandai hal di atas. 
“Tapi, kau tahu sendiri Bayu, Payudara itu tak pernah ada di dunia ini."

"Itu tak penting, Sakti. Yang penting adalah bahwa aku mencintai Payudara. Dan cintamu begitu tulus. Bukankah begitu, Sakti?”

"Ya, aku memang mencintainya, tapi aku tak tahu harus bagaimana?” (Syaifullah, 2004:21)

Absurditas perilaku dilakukan pula oleh tokoh Sakti ketika ia berkunjung ke rumah tokoh Bayu dan melihat para pasien yang ada di rumahnya. Tokoh Sakti saat itu juga menampakkan perilaku yang sangat konyol karena dirinya ingin ikut-ikutan berperilaku sama seperti orang-orang aneh yang berada di rumah Bayu, yang menganggap dirinya menjadi pasiennya, padahal sebelumnya tokoh Sakti tidak pernah memiliki kebiasaan berperilaku seperti yang dialami oleh para pasien tersebut. Kutipan berikut menandai hal di atas.

Pasien-pasien yang datang menghadap Bayu, selalu bertingkah aneh-aneh. Alasan ini pula yang menjadikan Sakti sering berkunjung ke tempat praktek Bayu. Ia amat senang menyaksikan tingkah laku orang-orang gila itu. Sampai-sampai Sakti pun ingin ikut-ikutan gila. (Syaifullah, 2004:24)

Absurditas perilaku tokoh Bayu semakin lama terus bertambah saat dirinya melakukan tindakan yang menyedihkan dan lucu, yakni ia terus memaksa para pengunjung yang ada di restoran untuk menaruh perhatian terhadap dirinya serta memaksa pengunjung tersebut untuk mengikuti apa yang ia perintahkan kepadanya. Ia mengeluarkan pisau sambil melakukan tindakan-tindakan yang menyedihkan dan terlihat lucu menjerit keras-keras. Kutipan berikut menandai hal di atas.

Bayu berdiri di salah satu meja makan, dan memaksa para pengunjung restoran untuk menaruh perhatian serius ke arahnya. Ia memaksa para pengunjung restoran untuk diam dan menatapnya.

"Saat ini, saudara-saudara harus tahu lebih jauh apa makna darah!”

Kemudian Bayu mengeluarkan pisau. Lalu ia menangis keras. Ia menjerit keras. (Syaifullah, 2004:26)

Perilaku tokoh Bayu semakin menunjukkan keabsurditasnnya, ia terus memperlihatkan perilaku yang aneh dan menyimpang dari akal sehat, karena apa yang dilakukan jelas-jelas menyimpang dari akal sehat, tidak mungkin seseorang yang terancam jiwanya akan melakukan tindakan atau perilaku tetap duduk dan tertawa saat dirinya ditembaki oleh para polisi, kecuali dilakukan oleh orang- 
orang yang tidak mempunyai akal sehat. Kutipan berikut menandai hal di atas.

"Stop! Hentikan penembakan! Tembakanmu semua percuma. Lihat, orang itu makin menertawakan kita," tegas Bapak Komandan seperti ingin 0 kata "goblok!" kepada anak-anak buahnya.

Bayu tetap duduk di atas kursi itu. Ia tetap saja tertawa (Syaifullah, 2004:28).

SIMPULAN

Berdasarkan hasil pembahasan, dapat disimpulkan beberapa hal. Pertama, Absurditas perilaku dalam drama Dag Dig Dug karya Putu Wijaya dimunculkan oleh tokoh suami, istri, tamu, Cokro, dan Ibrahim yang aneh. Kedua, Absurditas perilaku dalam novel Payudara karya Chavchay Syaifullah ditunjukkan oleh perilaku tokoh Bayu yang tidak masuk akal, tokoh Sakti yang berperilaku gila, Tokoh Komandan yang ingin membunuh tanpa sebab, dan Tokoh Martin yang ingin menyambut kemeriahan perkawinan tokoh Bayu dan Isabela (setan wanita). Ketiga, Persamaan absurditas perilaku dalam drama Dag Dig Dug karya Putu Wijaya dan novel Payudara karya Chavchay Syaifullah ditandai oleh halhal yang bersifat irrasional atau di luar nalar dan tidak masuk akal. Keempat, Perbedaan absurditas perilaku dalam drama Dag Dig Dug karya Putu Wijaya dan novel Payudara karya Chavchay Syaifullah terletak pada penggunaan setting dan konflik, drama Dag Dig Dug settingnya moton hanya di sekitar lingkungan rumah dan pekuburan dan konfliknya hanya membahas tentang kematian tokoh chairul umam, sedangkan dalam novel Payudara settingnya lebih banyak, dan konflik yang dimunculkan lebih beragam seperti perkawinan dengan setan, berbicara dengan lukisan, dan bergerak seperti mayat.

DAFTAR PUSTAKA

Aminuddin. 2011. Pengantar Apresiasi Karya Sastra. Malang: Sinar Baru Algensindo.

Arikunto, Suharsimi. 2006. Prosedur Penelitian: Suatu Penelitian Praktik. Jakarta: Rineka Cipta.

Bungin, M Burhan. 2010. Penelitian Kualitatif. Jakarta: Kencana.
Faruk, 2001. Beyond Imagination: Sastra Mutakhir dan Ideologi. Yogyakarta: Gema Media.

Moleong, Lexy J. 2005. Metodelogi Penelitian Kualitatif. Bandung: Remaja Rosda Karya.

Syaifullah, Chavchay. 2004. Payudara. Yogyakarta: Melibas. 